\title{
66. Studies on the Inhibition to Propagation of Ehrlich Ascites Tumor
}

\author{
By Kazuyuki Maekawa and Masahisa Kushibe \\ Faculty of Agriculture, Kyushu University, and Faculty of \\ Agriculture, Ehime University \\ (Comm. by Yuzuru OkUdA, M. J. A., April 12, 1969)
}

It has been shown that a complex (MA : Ehr. RNA) consisting of a RNA fraction (Ehr. RNA) isolated from Ehrlich ascites tumor cells and of methylated bovine serum albumin (MA) inhibits markedly the growth of the cells in vivo.1),2) When MA : Ehr. RNA had been injected intraperitoneally at certain intervals to mice after being inoculated with Ehrlich cells, the incidence of tumors was considerably reduced and about two third of the treated mice were not taken ill. The mice rescued from incidence of the tumor showed a strong resistance against the reinoculation of the same tumor. Hence, it is inferred that an anti-tumor factor might have been elicited in the surviving mice.

Other experiment showed that, when the mice had been injected intraperitoneally with tumor cells attenuated by MA : Ehr. RNAtreatment prior to the inoculation of tumors, the anti-tumor factor might have been produced in the bodies of the mice. ${ }^{3)}$ The present studies were undertaken in order to accomplish a complete inhibition of the tumor.

Experimentals. 1) Reinoculation and 3rd inoculation of mice rescued from the incidence of tumors.

Mice rescued from the incidence of tumors by means of MA : Ehr. RNA pretreatment were inoculated one year after the challenge inoculation with tumor cells, according to classes shown in Table I. The results obtained were as given also in the table, namely, although there is a considerable chasm in the tumor incidence of groups, responding to the amounts of inoculated cells, the mice definitely were not taken ill or survived longer than those of control.

Then, the 3rd inoculation was given 78 days after the 2 nd inoculation to the mice rescued in the 2nd inoculation. However, in this case no mice developed any tumors.

2) An adequate procedure for the inhibition to propagation of Ehrlich ascites tumor cells by means of MA : Ehr. RNA-treatment.

As seen from the results reported recently, ${ }^{3)}$ few of the mice injected with Ehrlich cells attenuated by MA : Ehr. RNA-treatment, developed tumors during the course of the treatment. Nevertheless, 
Table I. Reinoculation of the surviving mice

\begin{tabular}{c|c|c|c}
\hline Groups & $\begin{array}{c}\text { No. of cells } \\
\text { inoculated }\end{array}$ & No. of mice & $\begin{array}{c}\text { Mean values of log } \\
\text { (survival days) }\end{array}$ \\
\cline { 2 - 4 } Control mice & $10^{6}$ & 5 & 1.00 \\
\cline { 2 - 4 } & $10^{5}$ & 10 & 1.01 \\
\hline \multirow{4}{*}{ Mice rescued } & $2 \times 10^{4}$ & 5 & 1.04 \\
\cline { 2 - 4 } & $10^{6}$ & 1 & 1.31 \\
& $10^{5}$ & 3 & 1.33 \\
& $2 \times 10^{4}$ & 2 & survive \\
\hline & & 5 & 1.27 \\
& & 4 & survive \\
\hline
\end{tabular}

all of the rescued mice did not develop tumors in the challenge inoculation. Therefore, in the first place conditions of the attenuation were scrutinized.

Namely, Ehrlich ascites tumor cells $\left(10^{5}\right)$ were mixed with MA : Ehr. RNA suspension $(0.1 \mathrm{ml})$ of several different concentrations respectively. The mixtures were incubated at $25^{\circ} \mathrm{C}$ for $20 \mathrm{~min}$. under occasionally shaking and then were injected intraperitoneally in mice of each group. In 20 days after the injection, the challenge inoculation was given. The attenuation of Ehrlich cells applied to the $\mathrm{K}$ group might have been too mild and consequently the mean survival day of the mice was almost same as that of control. On the other hand, 7 of 9 animals belonging to the I group and all of the $J$

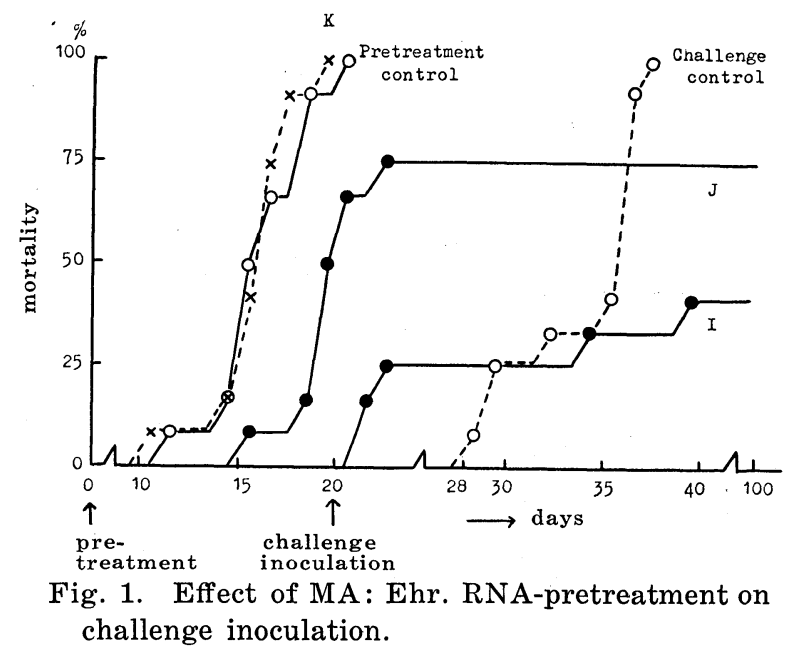


group did not develop tumors after the challenge inoculation (Fig. 1). Hence, it is implied that Ehrlich cells must be attenuated in a stronger way than that applied to the I group in order to inhibit the tumor incidence by such pretreatment and that the pretreatment must be tried repeatedly to enhance the induction of the anti-tumor factor.

As a next approach, $10^{5}$ of Ehrlich cells and $6 \mathrm{mg}$ of MA : Ehr. RNA (2.77: 1 by weight) were mixed at $25^{\circ} \mathrm{C}$ and were inoculated after incubating for $5 \mathrm{~min}$. at the same temperature. On the 10th day after the 1st pretreatment, the 2nd pretreatment was performed. This pretreatment was the same as the 1st. While all of the control mice developed tumors and died, none of the treated mice were taken ill. All of these survivors which had received the challenge inoculation 10 days after the 2nd pretreatment survived without any sign of tumor growth.

Finally, the conditions tried out for the attenuation of Ehrlich cells by means of MA : Ehr. RNA-treatment are summarized in Table II. All mice of the A, B and $\mathrm{C}$ groups treated under a condition

Table II. Summary of the results

\begin{tabular}{|c|c|c|c|c|c|c|c|}
\hline \multirow[b]{2}{*}{ Group } & \multicolumn{4}{|c|}{ Treatment } & \multicolumn{3}{|c|}{$\mathrm{S} / \mathrm{T}$} \\
\hline & $\begin{array}{l}\text { No. of } \\
\text { cells }\end{array}$ & $\begin{array}{l}\text { MA: Ehr. RNA } \\
\text { (2.77:1 by wt.) }\end{array}$ & Temp. & time & $\begin{array}{l}\text { After 1st } \\
\text { treatment }\end{array}$ & $\begin{array}{l}\text { After 2nd } \\
\text { treatment } \#\end{array}$ & $\begin{array}{l}\text { After } \\
\text { challenge } \\
\text { inocula- } \\
\text { tion* }\end{array}$ \\
\hline $\mathrm{K}$ & $10^{5}$ & $0.16 \mathrm{mg}$ & $25^{\circ}$ & 20 & $0 / 12$ & - & - \\
\hline $\mathrm{J}$ & , , & 0.8 & , , & , , & $3 / 12$ & - & $3 / 3$ \\
\hline I & , , & 4 & , , & , , & $9 / 12$ & - & $7 / 9$ \\
\hline A & , , & 4 & $25^{\circ}$ & $2-3$ & $8 / 8$ & - & $5 / 8$ \\
\hline B & , , & 8 & , , & , , & $8 / 8$ & - & $2 / 8$ \\
\hline $\mathrm{C}$ & & 12 & , , & , , & $8 / 8$ & - & $1 / 8$ \\
\hline D & , , & 6 & $5^{\circ}$ & 0 & $8 / 12$ & $8 / 8$ & $8 / 8$ \\
\hline $\mathrm{L}$ & , , & 6 & $25^{\circ}$ & 5 & $12 / 12$ & $12 / 12$ & $12 / 12$ \\
\hline
\end{tabular}

$\mathrm{S} / \mathrm{T}$ : No. of survivors/no. of test mice.

\#: The 2nd treatment was carried out on 10th day after the 1st treatment.

$*$ : The tumor cells $\left(10^{5}\right)$ were inoculated on 29 th day $(\mathrm{A}, \mathrm{B}, \mathrm{C})$, or 20 th day $(\mathrm{I}, \mathrm{J}, \mathrm{K})$, or 10 th day $(\mathrm{D}, \mathrm{L})$ after the last treatment.

of $25^{\circ} \mathrm{C}, 2-3$ min..$^{3)}$ survived in the pretreatment. Thus, the conditions applied at the pretreatment had been sufficient to attenuate Ehrlich cells. However, after the challenge inoculation more survivors were observed in the group pretreated with MA : Ehr. RNA of lower concentration. It was important to keep the cell attenuation as mild as possible and at the same time prevent the mice from being 
taken ill. Too weak an attenuation produced illness. From these results, it can be considered that the milder the cell was attenuated, to the extent that the mice were not taken ill, the higher the effect became in the challenge inoculation.

As a consequence, if mice are inoculated several times with the cells which have been appropriately attenuated so that they do not develop tumors by the pretreatment, the mice will produce an antitumor factor enough to inhibit the tumor development. In the D group, Ehrlich cells $\left(10^{5}\right)$ and $6 \mathrm{mg}$ of MA : Ehr. RNA were mixed at $5^{\circ} \mathrm{C}$ and then the mixture was immediately injected into the abdominal cavity of mice. Some of the mice of the D group developed tumors in the 1st treatment, while all of the $\mathrm{L}$ group incubated at $25^{\circ} \mathrm{C}$ for 5 min., survived without any sign of tumor growth in the treatment and also in the challenge inoculation. Therefore, as to the experiment of the L group, it was able to prevent completely the tumor incidence. However, for the adequate attenuating condition, it seems to be required a strict and limited condition as illustrated in Fig. 2.

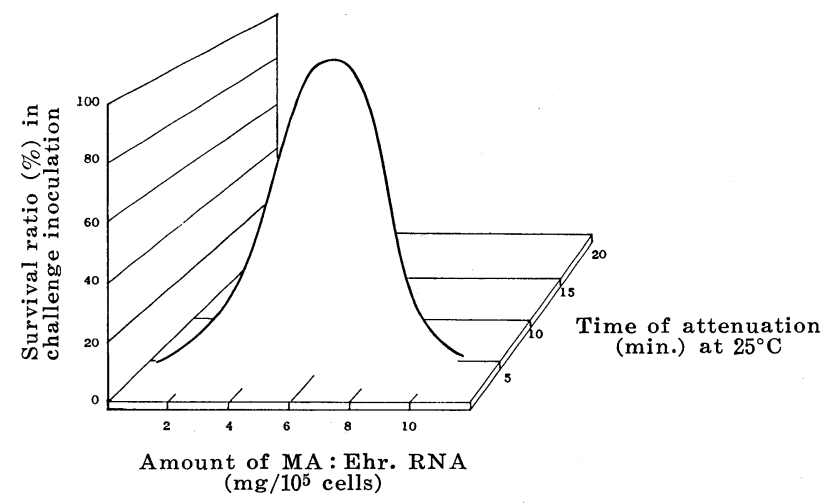

Fig. 2. An adequate pretreatment for complete prevention of the tumor incidence in the challenge inoculation.

Discussion. In recent years Hirai et al. isolated a tumor specific protein from hepatoma cells of rats and reported that an antibody against this protein was present in the serum of the rat which acquired resistance against the tumor inoculation.4)-7) Recently Lampson et $a l_{.8}{ }^{8)-11}$ revealed that a formation of an interferon in organisms was stimulated by double stranded RNA obtained from penicillium funiculosum, synthetized multi-stranded polynucleotide complex, double stranded RNA isolated from 3-type virion of reovirus, and double stranded RNA of replicative form of MS 2 coriphage respectively, and that double stranded DNA's did not have 
[Vol. 45,

any power to stimulate such formation. Isaacs also stated that single stranded RNA's originating from different species elicited the formation of the interferon. ${ }^{12)}$ But its activity is weaker than that induced by double stranded RNA's. Louisot et al. ${ }^{13)}$ reported on the inductive formation of the interferon by RNA. Thus, it may be presumed that the anti-tumor factor described here might be a substance of this kind. Therefore, using the serum prepared from the surviving mice, the agglutination test was tried with Ehrlich cells. Furthermore, using the substance prepared from Ehrlich cells by means of freezing and thawing, the precipitin test was also carried out. But both of the tests were quite negative. In the present status, therefore, the character of the anti-tumor factor remains to be described, but there is a strong probability that it may be an interferon.

\section{References}

1) K. Maekawa and M. Kushibe: Proc. Japan Acad., 43, 224 (1967).

2) —- 7th. Intern. Congr. Biochem. (Tokyo). Aug., 19-25 (1967), Abst. J.-14.

3) M. Kushibe, O. Ochi, Y. Kuwabara, and K. Maekawa: Proc. Japan Acad., 44, 558 (1968).

4) H. Hirai, K. Sekine, A. Iijima, and K. Warabioka: J. Biochem., 49, 682 (1961).

5) H. Hirai, H. Taga, and K. Warabioka: Ibid., 55, 178 (1964).

6) H. Hirai: Ibid., 57, 454 (1965).

7) H. Watanabe, S. Sato, and H. Hirai: Seikagaku, 39, 600 (1967).

8) G. P. Lampson, A. A. Tytell, A. K. Field, M. M. Nemes, and M. R. Hilleman: Proc. Nat. Acad. Sci., 58, 782 (1967).

9) A. K. Field, A. A. Tytell, G. P. Lampson, and M. R. Hilleman: Ibid., 58, 1004 (1967).

10) A. A. Tytell, G. P. Lampson, A. K. Field, and M. R. Hilleman: Ibid., 58, 1719 (1967).

11) A. K. Field, G. P. Lampson, A. A. Tytell, M. M. Nemes, and M. R. Hilleman: Ibid., 58, 2102 (1967).

12) A. Isaacs, R. A. Cox, and Z. Rotem: Lancet, 113 (1963-II).

13) P. Louisot and L. Colobert: Biochem. Biophys. Acta, 155, 38 (1968). 